\title{
Estimating soil water content in tallgrass prairie using remote sensing
}

\author{
PATRICK J. STARKS AND THOMAS J. JACKSON
}

Authors are Soil Scientist, USDA-ARS, Grazinglands Research Laboratory, El Reno, Okla. 73036, and Hydrologist, USDA-ARS, Hydrology Laboratory, Beltsville, Md. 20705.

\begin{abstract}
Increased demand for available water supplies necessitates that tools and techniques be developed to quantify soil water reserves over large land areas as an aid in management of water resources and watersheds. Microwave remote sensing can provide measurements of volumetric water content of the soil surface $\left(\theta_{\mathrm{vSL}}\right)$ up to about $10 \mathrm{~cm}$ deep. The objective of this study was to examine the feasibility of inferring the volumetric water content of the soil profile $\left(\theta_{\mathrm{vBL}}\right)$ by combining remotely sensed estimates of $\theta_{\mathrm{vSL}}$, in situ measurements, and modeling techniques. A simple soil water budget model was modified to estimate $\theta_{\mathrm{vBL}}$ from assimilated values of $\theta_{\mathrm{vSL}}$. Four modeling scenarios were evaluated at 4 tallgrass prairie sites located in central and south central Oklahoma: 1) unmodified model, 2) assimilation of field-measured $\theta_{\mathrm{vSL}}$ at 2-day intervals, 3) assimilation of field-measured $\theta_{\mathrm{vSL}}$ matching dates of remote sensing data acquisitions during the study period, and 4) assimilation of remotely sensed $\theta_{\mathrm{vSL}}$. The unmodified model (scenario 1) underestimated measurements with root mean square errors (RMSE) between 0.03 and $0.06 \mathrm{~m}^{3} \mathrm{~m}^{-3}$ and mean errors (ME) between 0.02 and $0.04 \mathrm{~m}^{3} \mathrm{~m}^{-3}$. Model output from scenario 2 agreed well with measurements at all study sites $\left(\mid \mathrm{MEI} \leq 0.01 \mathrm{~m}^{3} \mathrm{~m}^{-3}, \mathrm{RMSE} \leq 0.03\right.$ $\mathrm{m}^{3} \mathrm{~m}^{-3}$ ). The RMSE and ME values from scenario 3 were comparable to those of scenario 2 . Simulations from scenario 4 agreed well with measured data at 2 study sites $\left(0.00 \mathrm{~m}^{3} \mathrm{~m}^{-3} \geq \mathrm{ME} \leq 0.02\right.$ $\mathrm{m}^{3} \mathrm{~m}^{-3}$, RMSE $\leq 0.03 \mathrm{~m}^{3} \mathrm{~m}^{-3}$ ) but underestimated measurements at the remaining sites, in one case by as much as $0.15 \mathrm{~m}^{3} \mathrm{~m}^{-3}$. The underestimation was due largely to inaccurate remotely sensed $\theta_{\mathrm{vSL}}$ values. These preliminary results suggest that it is feasible to infer $\theta_{\mathrm{vSL}}$ in tallgrass prairies by combining remotely sensed estimates of $\theta_{\mathrm{vSL}}$, in situ field measurements, and modeling, provided that the remotely sensed data correctly estimates surface conditions.
\end{abstract}

Key Words: hydrology, microwave, water budget

Rangelands comprise over $60 \%$ of the land area of the 48 contiguous states, and agricultural, industrial, recreational, and municipal water supplies in many areas of the U.S. are linked directly to rangeland watershed management (Spaeth et al. 1996). An important part of the water budget of any watershed is the amount of water stored in the soil. Although soil water accounts

\footnotetext{
Manuscript accepted 30 Dec. 2001.
}

\section{Resumen}

La creciente demanda del suministro de agua disponible necesita que se desarrollen herramientas y técnicas para cuantificar las reservas de agua en el suelo en grandes extensiones como una ayuda en el manejo de los recursos de agua y las cuencas hidrológicas. Los sensores remotos de microondas pueden proveer de medidas del contenido volumétrico de la superficie $\left(\theta_{\mathrm{vSL}}\right)$ hasta cerca de $10 \mathrm{~cm}$ de profundidad. El objetivo de este estudio fue examinar la factibilidad de inferir el contenido volumétrico de agua del perfil del suelo $\left(\theta_{\mathrm{vBL}}\right)$ al combinar las estimaciones de sensores remotos de $\theta_{\mathrm{vSL}}$, mediciones in situ $y$ técnicas de modelaje. Un modelo simple de las reservas de agua se modifico para estimar $\theta_{\mathrm{vBL}}$ a partir de valores asimilados del $\theta_{\mathrm{vSL}}$. Se evaluaron cuatro escenarios de modelaje en cuatro sitios de pradera de zacates altos localizados en las regiones central y sur-central de Oklahoma: 1) El modelo sin modificaciones, 2) la asimilación de mediciones de campo del $\theta_{\mathrm{vSL}}$ a intervalos de 2 días, 3) la asimilación de mediciones de campo del $\theta_{\mathrm{vSL}}$ concordantes con las fechas de adquisición de datos de sensores remotos durante el periodo de estudio y 4) la asimilación del $\theta_{\mathrm{vSL}}$ a partir de sensores remotos. EI modelo sin modificar (escenario 1) subestimo las mediciones con la raíz de los cuadrados medios de los errores (RCME) entre 0.03 y $0.06 \mathrm{~m}^{3} \mathrm{~m}^{-3}$ y los errores medios (EM) entre 0.02 y $0.04 \mathrm{~m}^{3} \mathrm{~m}^{-3}$. El modelo resultante del escenario 2 concordó bien con las mediciones en todos los sitos de estudio $\left(\right.$ IEMI $\leq 0.01 \mathrm{~m}^{3} \mathrm{~m}^{-3}, \mathrm{RCME} \leq 0.03 \mathrm{~m}^{3} \mathrm{~m}^{-3}$ ). Los valores de RCME y EM del escenario 3 fueron comparables con los del escenario 2. Las simulaciones del escenario 4 concordaron bien con los datos obtenidos en dos sitios de estudio $(0.00$ $\mathrm{m}^{3} \mathrm{~m}^{-3} \geq \mathrm{ME} \leq 0.02 \mathrm{~m}^{3} \mathrm{~m}^{-3}, \mathrm{RCME} \leq 0.03 \mathrm{~m}^{3} \mathrm{~m}^{-3}$ ) pero subestimaron las mediciones en el resto de los sitios, en un caso por tanto como $0.15 \mathrm{~m}^{3} \mathrm{~m}^{-3}$. La subestimación se debió en gran parte a que los valores del $\theta_{\mathrm{vSL}}$ de los sensores remotos eran inexactos. Estos resultados preliminares sugieren que es posible inferir el $\theta_{\mathrm{vSL}}$ en las praderas de pastos altos mediante la combinación de estimaciones del $\theta_{\mathrm{vSL}}$ obtenidas a partir de sensores remotos, mediciones de campo en el sitio y modelaje y que los datos de sensores remotos estimaron correctamente las condiciones de la superficie.

for only about $0.0001 \%$ of the total water on earth, it is a key component in describing the transfer and distribution of mass and energy between the land surface and the atmosphere, it exerts major influences on forage and crop productivity, and it partitions rainfall into runoff and infiltration (Islam 1996). Increased 


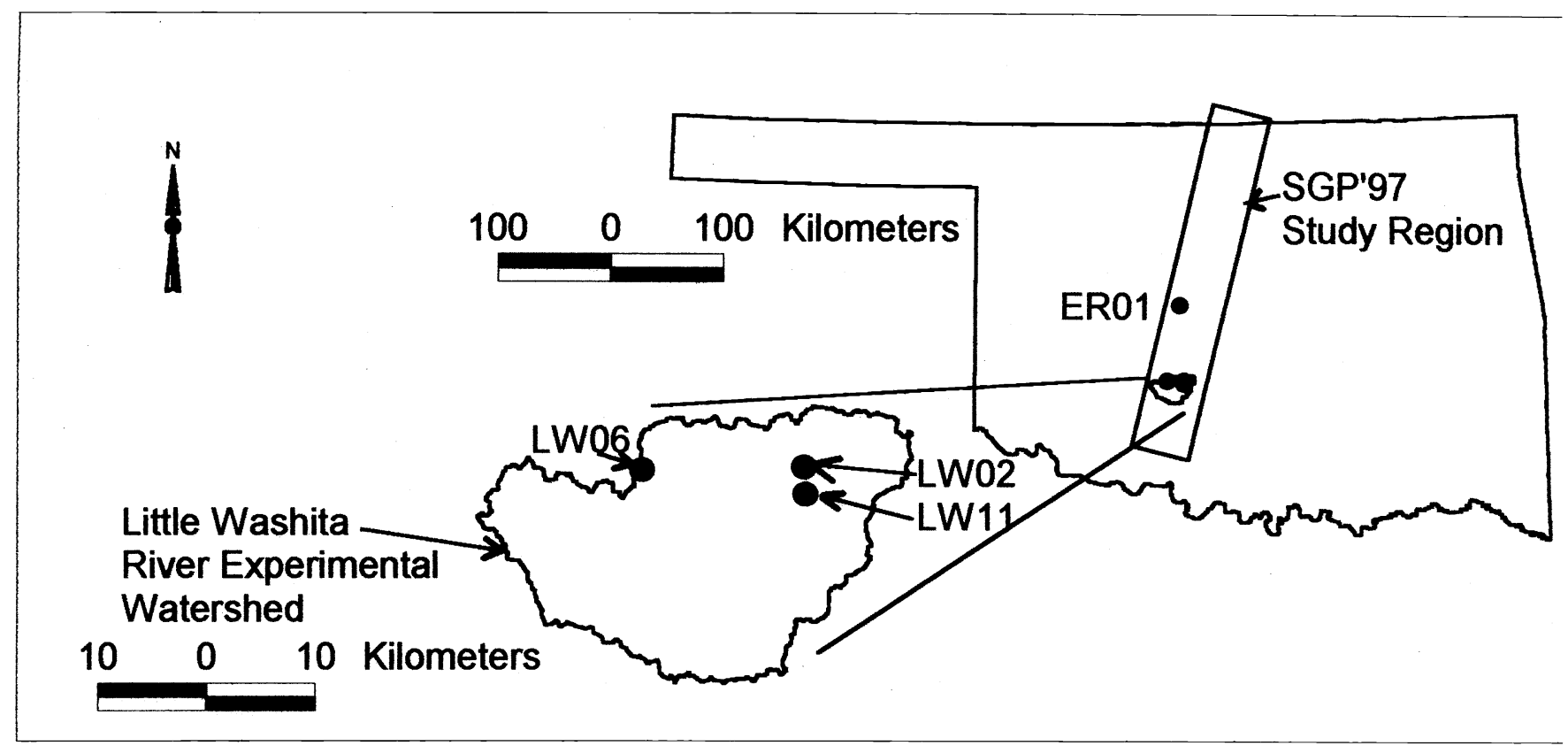

Fig. 1. Study site locations within the SGP ‘97 study area.

demand for available water supplies necessitates that tools and techniques be developed to quantify soil water resources over large land areas, such as rangelands, as an aid in management of water resources and watersheds. Equipping watersheds with soil water content measurement sites for routine monitoring is impractical and expensive, especially if the watershed is large or spatially variable in its topography, soil types, and vegetation cover. Remote sensing is a technique that offers potential for providing frequent measurements over large land areas in a timely and cost-effective manner.

Microwave remote sensing can provide measurements of volumetric water content $\left(\theta_{\mathrm{v}}\right)$ up to about $10 \mathrm{~cm}$ deep, depending upon sensor type and wavelength used (Engman and Chauhan 1995). The Southern Great Plains 1997 Hydrology Experiment (Jackson et al. 1999), referred to herein as SGP ' 97 , provides a recent example of attempts to use new microwave technologies to quantify surface soil water content $\left(\theta_{\mathrm{vSL}}\right)$ over large, spatially diverse regions at satellite spatial resolutions. One specific objective of SGP ' 97 , and the objective of this paper, was to examine the feasibility of inferring soil profile water content $\left(\theta_{\mathrm{vBL}}\right)$ by combining remotely sensed estimates of $\theta_{\mathrm{vSL}}$, in situ measurements, and modeling techniques (SGP 1997).

Ragab (1995) introduced a simple soil water budget model designed to incorporate $\theta_{\mathrm{vSL}}$ measurements (in situ or remotely sensed) to provide estimates of water content within the soil profile. The model requires basic meteorological data and easily obtained soil parameters, which makes it attractive for use in areas where little may be known about the underlying soils. The model was evaluated at 2 short grass pasture sites in England, and found to produce satisfactory results for those conditions (Ragab 1995), but the model was not used with remotely sensed data as input.

In this paper, remotely sensed $\theta_{\mathrm{vSL}}$ and in situ measurements are combined in Ragab's model to estimate $\theta_{\mathrm{vBL}}$ to a depth of $60 \mathrm{~cm}$. First, the original model's ability to reproduce measured time series of $\theta_{\mathrm{vBL}}$ is evaluated using measured meteorological, soil, and vegetation conditions at 4 experimental sites within the study area and period (18 June-16 July 1997) of the SGP ' 97 experiment.

Model simulations tend to drift because numerical algorithms are simplifications of complex physical processes. Because of this drift, data assimilation techniques may be employed whereby measured data are incorporated into the model to initialize or constrain the model to produce more realistic simulations. Applications of data assimilation arose within the meteorological community (Daley 1991), but the application of these techniques to remote sensing and soil water modeling is relatively new (e.g., Calvet et al. 1998, Houser et al. 1998, Wigneron et al. 1999a, 1999b; Hoeben and Troch 2000, Walker et al.
2001). A number of data assimilation techniques exist and they vary in complexity (Walker et al. 2001). The direct insertion technique is used herein to determine if assimilation of frequent, regularly-spaced field measurements of $\theta_{\mathrm{vSL}}$ improves model estimations of $\theta_{\mathrm{vBL}}$ compared to that provided by the original model. Next, the effect of assimilating field-measured $\theta_{\mathrm{vSL}}$ at irregular intervals is assessed. Lastly, remotely sensed estimates of $\theta_{\mathrm{vSL}}$ are assimilated into the model to detect the effects of remotely sensed observations of $\theta_{\mathrm{vSL}}$ on model estimates of $\theta_{\mathrm{vBL}}$.

\section{Materials and Methods}

\section{Site Descriptions}

Four study sites within the SGP ' 97 experimental area were chosen for model evaluation. Three of the sites (LW02, LW06, LW 11) were located on ARS' Little Washita River Experimental Watershed (LWREW), near Chickasha, Okla. (Lat. $34^{\circ} 53^{\prime}$ Long. $98^{\circ} 07^{\prime}$ ), and one (ER01) was located at ARS's Grazinglands Research Laboratory near El Reno, Okla. (Fig. 1). All of these sites were classified as native grassland (SGP 1997) and were dominated by big bluestem (Andropogon gerardii Vitman), little bluestem (Schizachyrium scoparium (Michx.) Nash), indiangrass (Sorghastrum nutans (L.) Nash) and switchgrass (Panicum virgatum L.). Despite similari- 
Table 1. Leaf area index (LAI) and biomass measurements for the study sites. These data were taken from Hollinger and Daughtry (1999).

\begin{tabular}{|c|c|c|c|c|c|c|c|c|c|c|}
\hline \multirow[t]{2}{*}{ Site } & \multirow[t]{2}{*}{ LAI } & \multicolumn{3}{|c|}{ Green Standing Biomass } & \multicolumn{4}{|c|}{ Brown Standing Biomass } & \multicolumn{2}{|c|}{$\begin{array}{c}\text { Surface Residue } \\
\text { (Litter) }\end{array}$} \\
\hline & & Wet & Dry & $\begin{array}{c}\text { Water } \\
\text { Content }\end{array}$ & Wet & Dry & Water & Wet & Dry & $\begin{array}{l}\text { Water } \\
\text { Content }\end{array}$ \\
\hline & & \multicolumn{2}{|c|}{$-\left(\mathrm{gm}^{-2}\right)$} & $-(\%-)-$ & \multicolumn{2}{|c|}{$---\left(\mathrm{gm}^{-2}\right)---$} & $-(\%)-$ & \multicolumn{2}{|c|}{$\left.-\mathrm{gm}^{-2}\right)-$} & $-(\%)-$ \\
\hline ER01 & 4.7 & 1403 & 460 & 67 & 133 & 97 & 26 & 967 & 510 & 47 \\
\hline LW02 & 2.2 & 350 & 161 & 53 & 184 & 158 & 19 & 160 & 141 & 14 \\
\hline LW06 & 0.9 & 112 & 41 & 62 & 22 & 18 & 17 & 18 & 12 & 10 \\
\hline LW11 & 3.6 & 940 & 246 & 73 & 67 & 44 & 43 & 494 & 319 & 35 \\
\hline
\end{tabular}

Table 2. Soil particle fractions and texture of the soil profile and taxonomy of the soils for each site.

\begin{tabular}{|c|c|c|c|c|c|}
\hline Site & Sand & Silt & Clay & Texture & Soil taxonomy \\
\hline $\begin{array}{l}\text { ER01 } \\
\text { silty, }\end{array}$ & 22 & $\begin{array}{l}(\%) \\
60\end{array}$ & 18 & Silt loam & $\begin{array}{l}\text { Pond Creek silt loam (fine- } \\
\text { mixed, thermic Pachic } \\
\text { Argiustolls) }\end{array}$ \\
\hline LW02 & 26 & 48 & 26 & Loam & $\begin{array}{l}\text { Lucien-Nash complex (loamy, } \\
\text { mixed, thermic, shallow Udic } \\
\text { Haplustolls) }\end{array}$ \\
\hline LW06 & 73 & 17 & 10 & $\begin{array}{l}\text { Sandy loam } \\
\text { Haplustalfs) }\end{array}$ & $\begin{array}{l}\text { Dougherty loamy fine sand } \\
\text { (loamy, mixed, thermic, Arenic }\end{array}$ \\
\hline LW11 & 54 & 24 & 22 & Sandy clay loam & $\begin{array}{l}\text { Nash loam (coarse-silty, mixed, } \\
\text { thermic Udic Haplustolls) }\end{array}$ \\
\hline
\end{tabular}

ties in species composition, Hollinger and Daughtry (1999) showed that other vegetation conditions varied widely between sites during the study period. For example, the leaf area index at ER01 was 4.7, while that at LW06 was 0.9. Additionally, litter mass at ER01 measured $510 \mathrm{~g} \mathrm{~m}^{-2}$ (on a dry matter basis), which is about 1.5 times that measured at site LW11 and 42 times that at LW06 (Table 1).

The soil profile at each site was sampled to a depth of $60 \mathrm{~cm}$ in $15 \mathrm{~cm}$ depth intervals using a coring tool with a $5 \mathrm{~cm}$ inside diameter. Depth intervals were divided into $7.5 \mathrm{~cm}$ long sub-samples. One subsample was used to determine soil texture using the hydrometer method (Day 1965).

Soil texture for the total soil profile was

Table 3. Surface $(0-5 \mathrm{~cm})$ and soil profile $(0-60 \mathrm{~cm})$ volumetric soil water contents $\left(\theta_{\mathrm{v}}\right)$ at field capacity (FC), wilting point (WP) and saturation (S) used in the model.

\begin{tabular}{llccc}
\hline \hline Site & Layer & $\theta_{\text {VFC }}$ & $\theta_{\text {VWP }}$ & $\theta_{\text {VS }}$ \\
\hline \multirow{2}{*}{ ER01 } & Surface & -0.32 & 0.24 & 0.41 \\
& Soil profile & 0.32 & 0.24 & 0.40 \\
\multirow{2}{*}{ LW02 } & Surface & 0.32 & 0.17 & 0.38 \\
& Soil profile & 0.31 & 0.11 & 0.35 \\
LW06 & Surface & 0.17 & 0.02 & 0.44 \\
& Soil profile & 0.17 & 0.02 & 0.41 \\
\multirow{2}{*}{ LW11 } & Surface & 0.29 & 0.05 & 0.38 \\
& Soil profile & 0.29 & 0.06 & 0.42 \\
\hline
\end{tabular}

\section{Meteorological and $\theta_{\mathbf{v}}$ Field Measurements}

Air temperature, rainfall, relative humidity, wind speed, incoming solar radiation, and barometric pressure were recorded at meteorological stations located at or near each study site. These data were used in a Penman-Monteith equation to calculate potential ET (ET ET $_{\text {at }}$ at sites LW06 and LW11. Actual ET (ET $)$ was calculated at sites ER01 and LW02 using the Bowen ratio/energy balance approach (Rosenberg et al. 1983).

A Soil Heat and Water Measurement System (SHAWMS) was installed at each of the 4 sites prior to SGP ' 97 . Each SHAWMS was placed inside a fenced enclosure measuring about $3.7 \mathrm{~m}$ on a side and about $1.3 \mathrm{~m}$ high. The vegetation within the enclosure was monitored regularly and managed to match surrounding field conditions as closely as possible. The SHAWMS instrumentation includes soil heat dissipation sensors (HDS) (Model 229, ${ }^{1}$ Campbell Scientific, Inc., Logan, Utah) which provided hourly measurements of $\psi$ with 3 replications at $5 \mathrm{~cm}$ and 1 replication each at $10,15,20,25$, and 60 $\mathrm{cm}$ below the soil surface. All HDSs were calibrated according to the method outlined in Starks (1999). Conversion of $\psi$ to $\theta_{\mathrm{v}}$ was based on the site- and depth-specific soil water release curves. The SHAWMS HDS output at 1200 hours (CST) was used to represent daily $\theta_{\mathrm{v}}$ since it was nearly co-incident with the time that the remotely sensed data were obtained over the area. Measured $\theta_{\mathrm{vBL}}$ was calculated as a weighted average of the HDS readings.

Elliott et al. (1999), Humes et al. (1999), Schneider et al. (1999), and Starks et al. (1999) found good correspondence between $\theta_{v}$ derived from HDSs and gravimetrically-based values, and to values obtained from various types of electronic sensors. The HDS-derived $\theta_{\mathrm{v}}$ tended to overestimate gravimetrically obtained values by about $0.02 \mathrm{~m}^{3} \mathrm{~m}^{-3}$, on average, at 3 study sites in Oklahoma (Starks 1999). When a sandy site was eliminated from the analysis, the overestimation was $\leq$ $0.01 \mathrm{~m}^{3} \mathrm{~m}^{-3}$. Humes (personal communication) compared $\theta_{\mathrm{v}}$ derived from both HDS and that determined gravimetrically from soil cores at a number of locations in Oklahoma and found that the HDS values

\footnotetext{
${ }^{\mathrm{I}}$ Names are necessary to report factually on available data; however, the USDA neither guarantees or warrants the standard of the product, and the use of the name by the USDA implies no approval of the product to the exclusion of others that may also be suitable.
} 
were within about $0.05 \mathrm{~m}^{3} \mathrm{~m}^{-3}$ of those obtained from the soil cores.

The HDSs tend to lose hydraulic contact with sandy soils and do not yield consistently reliable data under those conditions (Starks 1999). Therefore, at sites LW06 and LW11, gravimetric and time-domain reflectometry (TDR) measurements were used to determine $\theta_{\mathrm{vSL}}$ and $\theta_{\mathrm{vBL}}$, respectively. The TDR measurements at these 2 sites were obtained daily (weather permitting) during the 16 June-18 July experimental period within 2 hours of the remotely sensed data. An Environmental Sensors' MoisturePoint TDR (G.S. Gabel Corporation, British Columbia, Canada), utilizing 4-segment profiling rods, was used to sample the soil profile at $0-15$, $15-30,30-45$ and $45-60 \mathrm{~cm}$. Three readings were acquired per site per layer and were averaged to represent daily $\theta_{\mathrm{vBL}}$. The manufacturer's stated accuracy of the TDR is $\pm 3 \%$ of the instrument reading.

Nine soil samples, representing the $0-5$ $\mathrm{cm}$ surface layer, were collected once daily over a $20 \mathrm{~m}$ by $20 \mathrm{~m}$ grid at each site. Gravimetric soil water content was determined for each sample, averaged and multiplied by the respective soil's bulk density to obtain a representative value of $\theta_{\mathrm{vSL}}$ for each site. Standard deviations of the gravimetric soil water contents ranged between 0.01 and $0.04 \mathrm{~m}^{3} \mathrm{~m}^{-3}$.

\section{Remotely Sensed Data}

Remotely sensed images of surface microwave brightness temperatures $\left(\mathrm{T}_{\mathrm{B}}\right)$ were acquired over the $10,000 \mathrm{~km}^{2} \mathrm{SGP}$ ' 97 study area using the Electronically Scanned Thinned Array Radiometer (ESTAR). The ESTAR is an L band, synthetic aperture, passive microwave radiometer operating at a center frequency of $1.413 \mathrm{GHz}(21 \mathrm{~cm})$ and a bandwidth of $20 \mathrm{MHz}$. The ESTAR instrument was flown onboard a NASA P3B aircraft at an altitude of $7.5 \mathrm{~km}$. Postprocessing of the remotely sensed data produced a pixel size of $800 \mathrm{~m}$ by $800 \mathrm{~m}$. Because of weather conditions and equipment failures, the ESTAR was only able to collect data on 16 days of the 29 day study period. Nominal time over target was 0930 to 1130 hours local time.

Brightness temperatures measured by ESTAR are affected by a number of surface conditions which must be taken into account before a final $\theta_{\mathrm{vSL}}$ can be determined. Figure 2 is a diagram of the soil moisture retrieval algorithm used to convert $\mathrm{T}_{\mathrm{B}}$ to $\theta_{\mathrm{vSL}}$. Input requirements for the model are soil temperature at $15 \mathrm{~cm}$, vegetation type, vegetation water content, soil roughness, and soil texture. The model corrects $T_{B}$ for vegetation cover and surface roughness, and then estimates the soil's dielectric constant. Soil texture effects are then taken into account before inverting the dielectric mixing model (Wang and Schmugge 1980) to provide the final remote sensing images of $\theta_{\mathrm{vSL}}$. For additional details of the soil moisture algorithm see Jackson (1993).

Study site latitude and longitude coordiates were used in an image processing system to locate and extract $\theta_{\mathrm{vSL}}$ values from the ESTAR images, which were subsequently assimilated into the model.

\section{The Model}

The model is a one-dimensional soil water budget algorithm based on the force-restore concept presented by Bhumralkar (1975) for soil temperature, later adapted to soil water movement by Deardorff (1977). The model is divided into a surface layer (the remote sensing depth, $0-5 \mathrm{~cm}$ for this study) and a layer that extends from the soil surface to a user-defined depth (termed bulk layer by Ragab). In the remainder of this paper the term bulk layer will be used in preference to soil profile.

The model operates on a daily time step and the required meteorological data are daily values of rainfall and $\mathrm{ET}_{\mathrm{p}}$. The $\mathrm{ET}_{\mathrm{p}}$ values are adjusted within the model by a stress factor to estimate $\mathrm{ET}_{\mathrm{a}}$. The stress factor is the ratio of actual available to maximum available soil water content. The model was modified to bypass the stress adjustment when measured $\mathrm{ET}_{\mathrm{a}}$ values are used. Required soil parameters include depth of the surface and bulk layers; and, for each layer, $\theta_{\mathrm{vFC}}\left(\theta_{\mathrm{v}}\right.$ corresponding to $\psi$ of $-33 \mathrm{kPa}), \theta_{\mathrm{vWP}}\left(\theta_{\mathrm{v}}\right.$ corresponding to $\psi$ of $-1500 \mathrm{kPa}$ ), antecedent $\theta_{\mathrm{v}}$ (initial soil water content at the beginning of the model run), and maximum and minimum model-allowed $\theta_{\mathrm{V}}$ (prevents model estimates from being unrealistically wet or dry). The user can partition a portion of incident rainfall into runoff through the "surface runoff percentage" variable. This variable is initialized at the beginning of the model run and all subsequent rainfall events are partitioned in the same fashion. Since most rainfall events that occurred in this study were light, this variable was set to zero (i.e., no runoff). The "uptake ratio" variable is used to define the surface layer's contribution to $\mathrm{ET}_{\mathrm{a}}$. In this study the uptake ratio was set to 0.25 at all sites.

Dynamically, $\theta_{\mathrm{vSL}}$ is determined as a function of rainfall, runoff, $\mathrm{ET}_{\mathrm{a}}$, and the

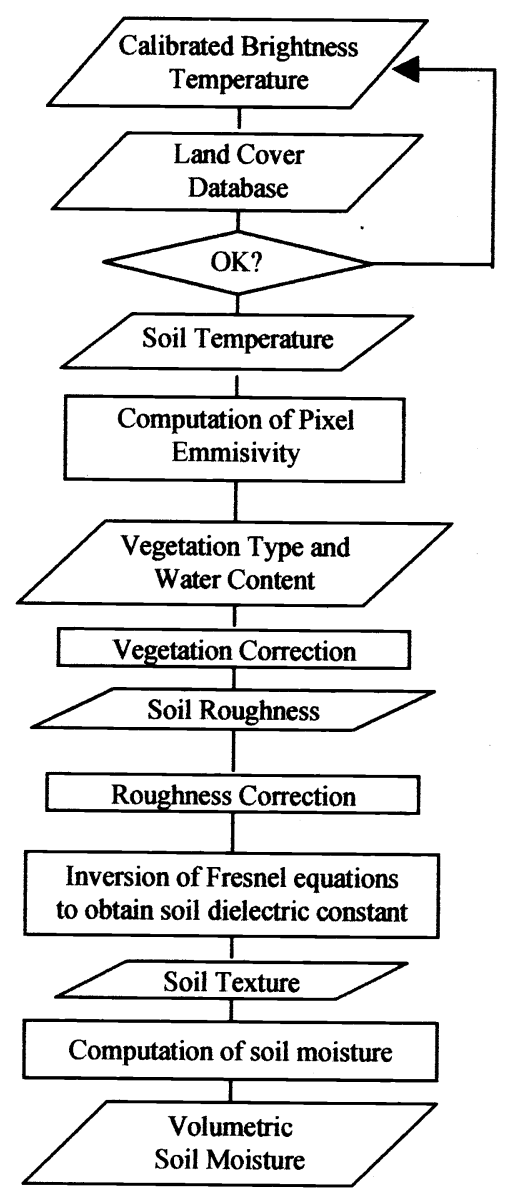

Fig. 2. Schematic of the soil moisture retrieval algorithm (adapted from Jackson, 1993).

amount of water in the bulk layer. The rate of exchange of water between the surface and bulk layer is governed by a pseudodiffusivity coefficient $(\mathrm{C})$, which depends upon surface soil texture and $\theta_{\mathrm{vBL}}$. The value of $C$ at our four study sites was empirically determined by running the model at sites with similar soils and making adjustments to $\mathrm{C}$ until the best match between model output and measured data was achieved.

Calculation of $\theta_{\mathrm{vBL}}$ is independent of surface layer computations and is a simple water budget requiring only daily values of rainfall, runoff, and ET. Thus, assimilation of surface $\theta_{\mathrm{vSL}}$ measurements into the original model will not affect bulk layer calculations. Therefore the original model was re-written in order that measurements of $\theta_{\mathrm{vSL}}$ could be assimilated into the model to infer $\theta_{\mathrm{vBL}}$. To this end, we adapted the statistical procedure outlined in Ragab (1995) for determining model initialization values for the bulk layer from surface measurements. This procedure utilizes site-specific linear regression equations, developed from field 
Table 4. Slope, intercept and coefficient of determination $\left(r^{2}\right)$ of linear regression equations used to convert remotely sensed surface $\theta_{\mathrm{v}}$ to root zone soil water storage $(\mathrm{mm})$. Root zone soil water storage is divided by depth of the root zone to estimate root zone $\theta_{\mathbf{v}}$.

\begin{tabular}{lccc}
\hline \hline Site & slope & intercept & $\mathrm{r}^{2}$ \\
\hline ER01 & 387.76 & 67.13 & 0.60 \\
LW02 & 309.58 & 67.02 & 0.74 \\
LW06 & 409.96 & 43.21 & 0.96 \\
LW11 & 307.96 & 86.33 & 0.90 \\
\hline
\end{tabular}

measurements, which relate $\theta_{\mathrm{vSL}}$ (in $\mathrm{m}^{3} \mathrm{~m}^{-3}$ ) to the depth of water stored (in $\mathrm{mm}$ ) in the bulk layer. Soil water storage values from the regression equations are divided by the bulk layer depth to yield updated values of $\theta_{\mathrm{vBL}}$. Correlation coefficients from the linear regressions (Table 4) are similar to those reported by Ragab (1995) for 2 soils in southern England.

The model was run for 4 scenarios. The first scenario examines the original model's ability to simulate $\theta_{\mathrm{vBL}}$ for the meteorologic, soil, and vegetation conditions at each of the study sites. In this scenario the initial $\theta_{\mathrm{vBL}}$ values are supplied from field-measured data. The model then produces a time series of $\theta_{\mathrm{vBL}}$ based only upon the meteorological drivers of rainfall and $\mathrm{ET}_{\mathrm{a}}$ and the measured soil and vegeta- tion parameters initially supplied to the model. In the second scenario, field measurements of $\theta_{\mathrm{vSL}}$ are assimilated into the model at 2-day intervals to determine if model simulations of $\theta_{\mathrm{vBL}}$ are improved over that of scenario 1. The 2-day interval was chosen in response to the frequency of surface soil moisture products that may become available on future satellite platforms. For example, the European Space Agency's ENVISAT has a primary repeat coverage cycle of 35 days, but will have coverage subcycles of 1,3 , and 17 days (http://envisat.esa.int/ accessed 7 Jan. 2002). In scenario 3, field measurements are again used to update the model but only on those days corresponding to the times when the ESTAR was used to collect data during the study period. Since the ESTAR did not fly every day during the study period, this scenario examines the effect of irregular and/or infrequent data assimilation on model simulations during the study period. In the fourth scenario, ESTAR data, which represents a $800 \mathrm{~m}$ by $800 \mathrm{~m}$ spatial average of $\theta_{\mathrm{vSL}}$, are assimilated into the model.

\section{Statistical Analysis}

Willmott and Wicks (1980) and Willmott $(1981,1982)$ raised concerns about the exclusive use of $r$ and $r^{2}$ in the context of evaluating model performance. Willmott (1981) noted that very dissimilar values of measurements and estimates can produce an $r$ very near 1, while small differences between measured and estimated quantities can produce a low or even negative $\mathrm{r}$ (Willmott and Wicks 1980). Willmott (1982) proposed the d-index of model agreement which, when used in conjunction with other common statistical measures, aids in evaluating the accuracy of models. A $d=1$ indicates complete agreement between modeled and measured values, and $d=0$ indicates complete disagreement. The $\mathrm{d}$-index is used herein to evaluate how well model output agrees with measured field data for each of the 4 scenarios. In addition, the mean error (ME) and root mean square error (RMSE) were used to describe the average difference between modeled and measured values and to describe the average total error in the estimating procedure, respectively. A no-intercept linear regression analysis was used to determine $r^{2}$ and regression coefficients (slope, designated $\beta_{1}$ ) between measured and modeled values. A $t$-test was used to determine if the modeled values are significantly different from measured values by testing the null hypothesis, Ho: $\beta_{1}=1$. Preliminary analy-
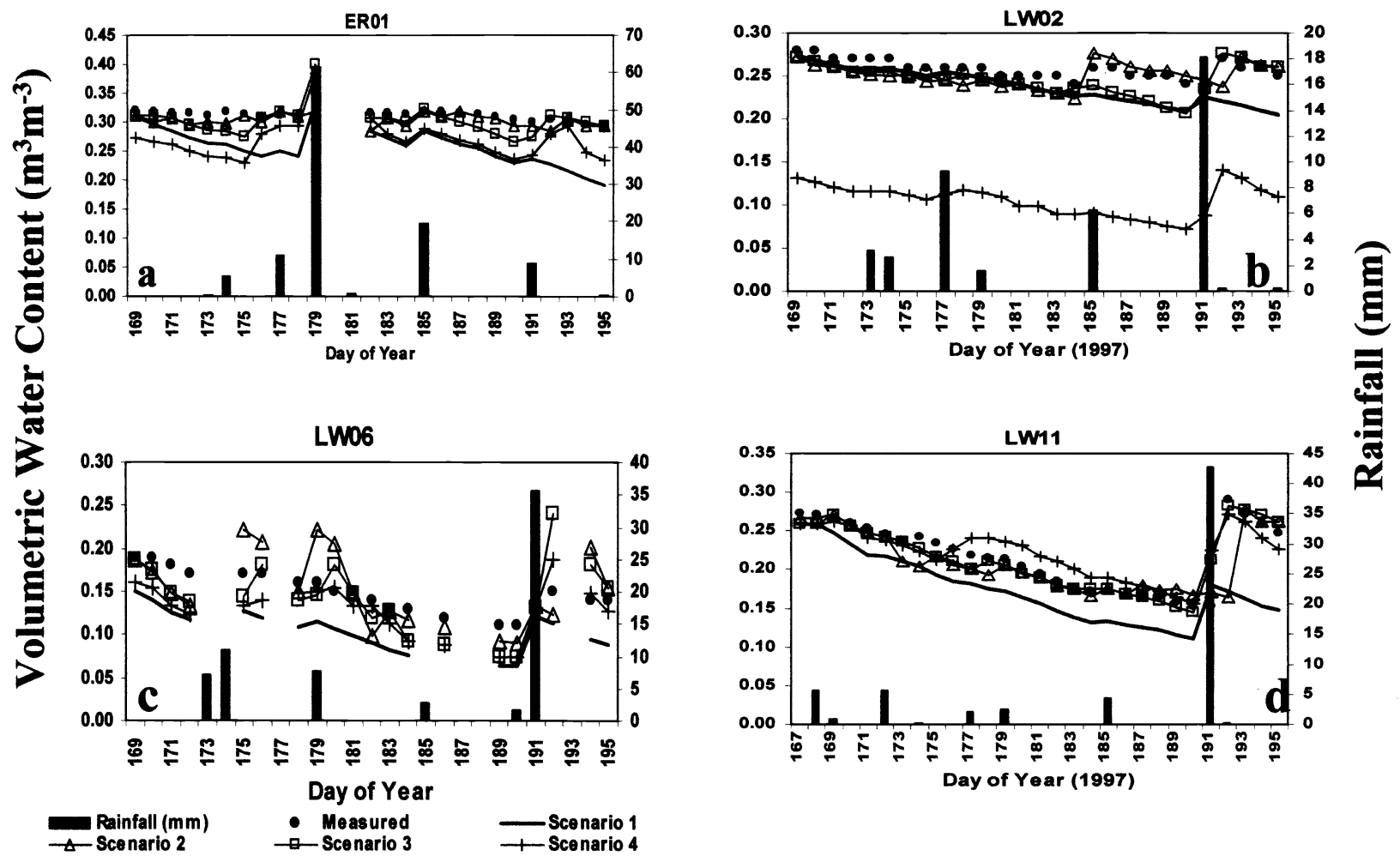

Fig. 3. Time series plots of measured and modeled bulk layer volumetric soil water content for study sites ER01 (a), LW02 (b), LW06 (c), and LW11 (d) during the experimental period. Gaps in the time series reflect days when measured values were unavailable for comparison with modeled output. 
Table 5. Results from the statistical analysis of the comparison of modeled and measured bulk layer soil water content for each scenario.

\begin{tabular}{|c|c|c|c|c|c|c|c|c|c|c|}
\hline \multirow[b]{2}{*}{ Site ID } & \multicolumn{5}{|c|}{ Scenario 1} & \multicolumn{5}{|c|}{ Scenario 2} \\
\hline & $d^{1}$ & $\mathrm{ME}^{2}$ & RMSE & $\beta_{1}$ & $r^{2}$ & $\mathrm{~d}$ & ME & RMSE & $\beta_{1}$ & $r^{2}$ \\
\hline & \multicolumn{5}{|c|}{$\left(\mathrm{m}^{3} \mathrm{~m}^{3}\right)$} & \multicolumn{5}{|c|}{$-\left(\mathrm{m}^{3} \mathrm{~m}^{3}\right)-\cdots$} \\
\hline ER01 & 0.25 & 0.05 & 0.06 & $1.201^{* *}$ & 0.990 & 0.58 & 0.01 & 0.01 & 1.028 & 0.999 \\
\hline LW02 & 0.52 & 0.02 & 0.03 & $1.088^{* *}$ & 0.996 & 0.59 & 0.01 & 0.01 & 1.018 & 0.997 \\
\hline LW06 & 0.56 & 0.04 & 0.05 & $1.399 * *$ & 0.985 & 0.78 & 0.00 & 0.02 & 1.000 & 0.972 \\
\hline \multirow[t]{2}{*}{ LW11 } & 0.69 & 0.05 & 0.06 & $1.235^{* *}$ & 0.973 & 0.88 & 0.01 & 0.03 & 1.014 & 0.984 \\
\hline & \multicolumn{5}{|c|}{ Scenario 1} & \multicolumn{5}{|c|}{ Scenario 2} \\
\hline \multirow[t]{2}{*}{ Site ID } & $\mathrm{d}^{1}$ & $\mathrm{ME}^{2}$ & RMSE & $\beta_{1}$ & $r^{2}$ & d & $\mathrm{ME}$ & RMSE & $\beta_{1}$ & $\mathrm{r}^{2}$ \\
\hline & \multicolumn{4}{|c|}{$-\left(\mathrm{m}^{3} \mathrm{~m}^{3}\right)-\cdots$} & \multicolumn{6}{|c|}{$-\left(\mathrm{m}^{3} \mathrm{~m}^{3}\right)-$} \\
\hline ER01 & 0.37 & 0.01 & 0.02 & 1.021 & 0.995 & 0.23 & 0.04 & 0.05 & $1.142^{* *}$ & 0.989 \\
\hline LW02 & 0.66 & 0.01 & 0.02 & 1.037 & 0.997 & 0.12 & 0.15 & 0.15 & $2.371^{* *}$ & 0.982 \\
\hline LW06 & 0.72 & 0.01 & 0.03 & 0.984 & 0.956 & 0.73 & 0.02 & 0.03 & $1.123 * *$ & 0.986 \\
\hline LW11 & 0.97 & 0.00 & 0.02 & 0.995 & 0.998 & 0.91 & 0.00 & 0.02 & 0.984 & 0.991 \\
\hline
\end{tabular}

**Significant at the 0.01 level

$\mathrm{I} d=1-[\Sigma \text { (Modeled - Measured })^{2} / \Sigma\left(\right.$ Modeled - Mean of Measured $\left.\right|^{2}+\mid$ Measured - Mean of Measured $\left.\left.\left.\right|^{2}\right)\right]$

${ }^{2} \mathrm{ME}=\sum$ (Measured - Modeled $) / \mathrm{n}$

${ }^{3} \mathrm{RMSE}=\left[\Sigma(\text { Modeled }- \text { Measured })^{2} / \mathrm{n}\right] 1 / 2$

sis showed that the residual lack of fit in the no-intercept regression analyses was small and not a realistic estimate of the true error because of the extremely good fit of the model output to the measured data. Thus, an error of $0.03 \mathrm{~m}^{3} \mathrm{~m}^{-3}$ in the HDS and TDR measurements is assumed and is used as an approximation of the standard error of the estimate in the $t$ equation. Since the study objective relates to the bulk layer, only the results from that layer are reported.

\section{Results}

\section{Scenario 1 - Original Model}

The range of measured $\theta_{\mathrm{vBL}}$ over the course of the study period was about 0.04 $\mathrm{m}^{3} \mathrm{~m}^{-3}$ at sites ER01 and LW02, $0.08 \mathrm{~m}^{3} \mathrm{~m}^{-3}$ at LW06, and $0.14 \mathrm{~m}^{3} \mathrm{~m}^{-3}$ at LW11. These ranges of measured $\theta_{\mathrm{vBL}}$ represent 50,20 , 93 , and $61 \%$ of the total plant available water (defined as the difference in water content at field capacity and wilting point) at these sites, respectively. Time series simulations from the original model exhibit the general patterns portrayed by the measured data, but the model consistently underestimated measured values at all sites (Figs. 3a-3d). The differences between measured and modeled $\theta_{\mathrm{vBL}}$ generally increase with time at sites ER01 and LW02, while at sites LW06 and LW11 there appears to be a constant offset or bias in the model simulations (Figs. $3 a-3 d)$.

The $r^{2}$ values indicate that the variation in the modeled values is strongly associated with the variation in the measurements at all sites (Table 5), but the $\beta_{1}$ are significantly different from a slope of 1 , indicating that the modeled output does not approximate measured values well. The dindex (Table 5), however, indicates weak agreement between measured and modeled values at ER01, moderate agreement at sites LW02 and LW06, and stronger agreement at LW11. The ME reveals that the model underestimated measured values from $0.02 \mathrm{~m}^{3} \mathrm{~m}^{-3}$ at site LW02 to 0.05 $\mathrm{m}^{3} \mathrm{~m}^{-3}$ at site ER01. Only site LW02 had a RMSE $\leq 0.05 \mathrm{~m}^{3} \mathrm{~m}^{-3}$.

\section{Scenario 2}

Assimilation of field-measured $\theta_{\mathrm{vSL}}$ values into the model at frequent, evenlyspaced intervals brings the model estimates of $\theta_{\mathrm{vBL}}$ into close agreement with measured values (Figs. 3a-3d). Neither the steadily increasing differences or constant offset from measured values noted in the simulations of scenario 1 is observed here.

The d-index increased at all sites, with the greatest improvement observed at ER01. At all study sites, the RMSE were $\leq 0.03$ $\mathrm{m}^{3} \mathrm{~m}^{-3}$, a two-fold reduction at each site compared to scenario 1 (Table 5). The absolute values of ME were all $\leq 0.01$ $\mathrm{m}^{3} \mathrm{~m}^{-3}$, a reduction of at least $0.04 \mathrm{~m}^{3} \mathrm{~m}^{-3}$ at all sites, except at LW02 where the ME was reduced by $0.01 \mathrm{~m}^{3} \mathrm{~m}^{-3}$. The $\beta_{1}$ values at all sites were not significantly different from a slope of 1 , indicating that the model output closely approximates the measured values.

\section{Scenario 3}

Assimilation of field-measured $\theta_{\mathrm{vSL}}$ into the model at irregular intervals produced mixed results. At site ER01, the d-index decreased considerably in comparison to scenario 2, although the ME remained unchanged and the RMSE increased by only $0.01 \mathrm{~m}^{3} \mathrm{~m}^{-3}$ to $0.02 \mathrm{~m}^{3} \mathrm{~m}^{-3}$ (Table 5). Comparison of the time series plots (Fig. 3a) shows that scenarios 2 and 3 produced similar output except during consecutive days when assimilation data were unavailable (DOY 172-175, 185-191). At site LW02, the d-index increased slightly over that observed in scenario 2, the ME remained unchanged and the RMSE increased by $0.01 \mathrm{~m}^{3} \mathrm{~m}^{-3}$. The largest discrepancies between measured and modeled data at site LW02 occurred during the 7 days from DOY 185-191 (Fig. 3b) when field measurements of $\theta_{v S L}$ were not available to the model. The effect of assimilating $\theta_{\mathrm{vSL}}$ data at irregular intervals had a small negative effect at site LW06 (Fig. 3c) as indicated by a slight decrease in the d-index and an increase of $0.01 \mathrm{~m}^{3} \mathrm{~m}^{-3}$ in the ME and RMSE (Table 5) over that observed in scenario 2. At site LW11 (Fig. 3d) the d-index (Table 5) indicates near-perfect agreement between modeled and measured values. Additionally, the ME and RMSE decreased by $0.01 \mathrm{~m}^{3} \mathrm{~m}^{-3}$ from those observed in scenario 2 . It should be noted that the statistical analysis from this scenario shows improved simulations at all sites over that obtained in scenario 1; all $\mathrm{d}$-indices are larger and all ME and RMSE values smaller than their counterparts in scenario 1 . As in scenario 2 , the $\beta_{1}$ values were found to be statistically similar to a slope of 1 .

\section{Scenario 4}

Model output at sites ER01 and LW02 did not agree well with measured data (dindex $\leq 0.23$ ) (Figures 3a-d, Table 5). At site ER01, both the ME and RMSE increased by $0.03 \mathrm{~m}^{3} \mathrm{~m}^{-3}$ over that observed in scenario 3. Regression coefficients at these 2 sites are statistically different from a slope of 1 , suggesting that 
modeled $\theta_{\mathrm{vBL}}$ does not adequately approximate measured values. At site LW02, assimilation of remotely sensed $\theta_{\mathrm{vSL}}$ into the model produced ME and RMSE values larger than any others encountered in the study. In contrast, the d-index, ME and RMSE values at sites LW06 and LW11 are comparable to those in scenarios 2 and 3, indicating good agreement with measured values. However, the $\beta_{1}$ at LW06 is statistically different from a slope of 1 .

\section{Summary and Conclusions}

The objective of this paper was to examine the feasibility of inferring $\theta_{\mathrm{vBL}}$ by combining remotely sensed estimates of surface water content, in situ measurements, and modeling techniques. The model of Ragab (1995) was selected for this study because of its simplicity and because it does not require detailed soil physical and hydraulic and vegetation properties to parameterize the model-properties that are not generally available or easily measured over large and/or spatially variable watersheds. This is particularly advantageous for applications where little is known about an area's soil physical properties, since the required model inputs may be estimated from general soil texture information (e.g., Rawls et al. 1982).

The original model was able to reproduce the time series patterns of $\theta_{\mathrm{vBL}}$, but consistently underestimated measured values from 0.02 to $0.05 \mathrm{~m}^{3} \mathrm{~m}^{-3}$, on average, depending upon study site. Under-estimation of $\theta_{\mathrm{vBL}}$ may be a result of overestimation of daily $\mathrm{ET}_{\mathrm{a}}$. The simplistic stress factor adjustment used in the model, to reduce the user-supplied daily $\mathrm{ET}_{\mathrm{p}}$ values to more closely approximate $\mathrm{ET}_{\mathrm{a}}$, is calculated as the ratio of actual water available in a given layer of the soil to the maximum amount of water that layer could hold. This adjustment algorithm does not explicitly take into account the various resistances that may reduce the flow of water from the soil, through the plant and into the atmosphere. At 2 study sites, measured values of $\mathrm{ET}_{\mathrm{a}}$ were used in place of $\mathrm{ET}_{\mathrm{p}}$, and the stress factor adjustment bypassed in the model. Even at these sites, $\mathrm{ET}_{\mathrm{a}}$ may have been overestimated since the values supplied from the Bowen ratio measurements may have reflected contributions from below the $0-60 \mathrm{~cm}$ layer that was modeled.

Since numerical algorithms are approximations of complex physical processes, the model was re-written to determine if assimilation of $\theta_{\mathrm{vSL}}$ observations could improve model estimates of $\theta_{\mathrm{vBL}}$. The data assimilation technique used either field-measured or remotely sensed $\theta_{\mathrm{vSL}}$ values in site-specific linear regression equations to infer $\theta_{\mathrm{vSL}}$ within the model. When field observations of $\theta_{\mathrm{vSL}}$ were assimilated at regular and frequent intervals (scenario 2), the model simulations were improved and model output agreed well with measurements at all sites. When the field observations were assimilated at irregular intervals (scenario 3), model output agreed well with measured data at all but 1 site. However, scenario 3 simulations at all study sites showed improvement over that provided by the original model (scenario 1). In general, assimilation of field-measured $\theta_{\mathrm{vSL}}$ into the model resulted in $\theta_{\mathrm{vSL}}$ estimates that compared well to measured values.

Remotely sensed observations of $\theta_{\mathrm{vSL}}$ were assimilated into the model to determine the effects on estimation of $\theta_{\mathrm{vBL}}$ (scenario 4). Modeling results at sites LW06 and LW11 were similar to those produced by scenarios 2 and 3 (i.e., good agreement between measured and modeled values as indicated by the d-index, ME and RMSE statistics). Results from the $t$-tests showed that the $\beta_{1}$ obtained at LW06 was statistically different from a slope of 1 , suggesting that the modeled output did not agree well with the measured data. The reason for this is not clear since the statistics (d-index, ME and RMSE) from scenario 4 are very similar to those from scenario 3 at this site. It is not likely that the vegetation adversely affected the remotely sensed data (discussed below) because LW06 had the lowest leaf area index of all the study sites. It is possible that the measured $\theta_{\mathrm{vBL}}$ data (obtained at a point) did not adequately represent the $800 \times 800 \mathrm{~m}$ area observed by the remotely sensed data.

When remotely sensed data were assimilated into the model at sites ER01 and LW02, the model output underestimated measurements throughout the study period. At site ER01, the modeling results were similar to those observed in scenario 1 , but the simulation at site LW02 underestimated measured values by about 0.15 $\mathrm{m}^{3} \mathrm{~m}^{-3}$ throughout the study period. Underestimation of $\theta_{\mathrm{vBL}}$ at these 2 sites is apparently a result of vegetational effects on the ESTAR data. Jackson et al. (1999) noted that tall grasses and heavy litter deposits will cause the ESTAR moisture retrieval algorithm to underestimate $\theta_{\mathrm{vSL}}$. Site ER01 was the most densely vegetated of the study sites and possessed the heavi- est litter layer. Although site LW02 was classified as a rangeland site, there are a number of trees in the area and, like tall grasses and dense litter layers, trees lead to underestimation of ESTAR $\theta_{\mathrm{vSL}}$. Thus, assimilated remotely sensed $\theta_{\mathrm{vBL}}$ values from these sites probably led to underestimated bulk layer values. Jackson et al. (1999) indicated that adjustments to vegetational aspects of the ESTAR soil moisture retrieval algorithm can be made to better account for litter and trees. These adjustments will be necessary if microwave-based remote sensing techniques are to be widely used to assess soil water content. The results from scenario 4 suggest that it is feasible to infer $\theta_{\mathrm{vBL}}$ in tallgrass prairies by combining remotely sensed observations of $\theta_{\mathrm{vBL}}$ into a soil water budget model, provided that the remotely sensed data has not been corrupted by vegetational effects.

The assimilation procedure used in this study was based upon a linear regression approach suggested by Ragab (1995) for determining bulk layer model initialization values from surface measurements. This approach is simple, and worked well at the study sites over the course of the study period, but the approach is empirical and may not produce satisfactory results over longer periods or in the presence of layered soils (e.g., sandy textured surface soil overlaying clay). An alternate approach would be to use a multiple regression equation that would take into account time since the last rainfall event, precipitation amount, and soil texture. The linear equations developed here should not be expected to apply to other locations having different soil, vegetation, and climate conditions.

A remote sensing/modeling approach such as that described above could be integrated with weather forecasts and/or climate outlooks to project future soil water supplies, as well as assessing the current status of soil water content. Such assessments and predictions could be used by agricultural producers and others to schedule irrigation and predict crop or forage production rates, and by water resources managers to better manage watersheds and surface, soil, and groundwater water resources.

\section{Literature Cited}

Ahuja, L.R., J.W. Naney, and R.D. Williams. 1985. Estimating soil water characteristics from simpler properties or limited data. Soil Sci. Soc. Amer. J. 49:1100-1105. 
Bhumralkar, C.M. 1975. Numerical experiments on the computation of ground surface temperature in an atmospheric general circulation model. J. App. Meteor. 14:1246-1258.

Calvet, J.C., J. Noilhan, and P. Bessemoulin. 1998. Retrieving the root zone soil moisture or temperature estimates: a feasibility study based on field measurements. J. App. Meteor. 37:371-386.

Daley, R. 1991. Atmospheric Data Analysis. Cambridge University Press. New York.

Day, P.R. 1965. Particle fractionation and particle-size analysis. In: C.A. Black et al. (eds.) Methods of soil analysis-Part 1. Agron. 9:545-567. Amer. Soc. Agron., Madison, Wis.

Deardorff, J.W. 1977. A parameterization of ground surface moisture content for use in atmospheric prediction models. J. App. Meteorol. 16:1182-1185.

Elliott, R.L., P.R. Houser, and B.P. Mohanty. 1999. Inter-comparison of three methods for measuring soil moisture during SGP97. Preprint Volume, $14^{\text {th }}$ Conf. Hydrol, 10-15 Jan., Dallas, Tex., Amer. Meteorol. Soc., pp. 178-181.

Engman, E.T. and N. Chauhan. 1995. Status of microwave soil moisture measurement with remote sensing. Rem. Sen. Envir. 51:189-198

Hoeben, R. and P.A. Troch. 2000. Assimilation of active microwave observation data for soil moisture profile estimation. Water Resourc. Res. 36:2805-2819.

Hollinger, S.E. and C.S.T. Daughtry. 1999. Southern Great Plains 1997 hydrological experiment: vegetation sampling and data documentation. Internet document site http://daac.gsfc.nasa.gov/CAMPAIGN_DOC S/SGP97/sgpvegdatrptv3b.html (Accessed 7 Jan. 2002)

Houser, P.R., W.J. Shuttleworth, J.S. Famiglietti, H.V. Gupta, K.H. Seyed, and D.C. Goodrich. 1998. Integration of soil moisture remote sensing and hydrologic modeling using data assimilation. Water Resour. Res. 34:3405-3745.
Humes, K.S., R.L. Elliott, J.B. Basara, K.C. Crawford, and T.J. Jackson. 1999. Comparison of soil moisture estimates from the Oklahoma Mesonet and passive microwave remote sensing. Preprint Volume, $14^{\text {th }}$ Conf. Hydrol, Dallas, TX., Amer. Meteorol. Soc., pp. 188-191.

Islam, S. 1996. Why bother for $0.0001 \%$ of Earth's water? Challenges for soil moisture research. EOS Trans. Amer. Gephys. Union 77 (43): 420.

Jackson, T.J. 1993. Measuring surface soil moisture using passive microwave remote sensing. Hydrol. Processes 7:139-152.

Jackson, T.J., D.M. Le Vine, A.Y. Hsu, A. Oldak, P.J. Starks, C.T. Swift, J.D. Isham, and M. Haken. 1999. Soil moisture mapping at regional scales using microwave radiometry: the Southern Great Plains hydrology experiment. IEEE Trans. Geosci. Rem. Sen. 37:2136-2151.

Ragab, R. 1995. Towards a continuous operational system to estimate the root-zone soil moisture from intermittent remotely sensed surface moisture. J. Hydrol. 173:1-25.

Rawls, W.J., D.L. Brakensiek, and K.E. Saxton. 1982. Estimation of soil water properties. Trans. ASAE 25:1316-1320.

Rosenberg, N.J., B.L. Blad, and S.B. Verma 1983. Microclimate: The Biological Environment. John Wiley and Sons, Inc., New York, N.Y.

Schneider, J.M., P. Starks, and D.K. Fisher. 1999. Comparison of DoE ARM/CART SWATS, USDA/ARS SHAWMS, and other in situ soil moisture measurements during SGP97. Preprint Volume, $14^{\text {th }}$ Conf. Hydrol., Dallas, Tex., Amer. Meteorol. Soc., pp. 184-187.

SGP. 1997. Southern Great Plains 1997 (SGP97) Hydrology Experiment Plan: June 18-July 18, 1997, 178 pp. Internet document site http://hydrolab.arsusda.gov/ tjackson/ (Accessed 7 Jan. 2002)

Spaeth, K.E., T.L. Thurow, W.H. Blackburn, and F.B. Pierson. 1996. Ecological dynamics and management effects on rangeland hydrologic processes. In: Spaeth et al. (eds), Grazingland Hydrology Issues: Perspectives for the $21^{\text {st }}$ Century. Soc. Range Manage. Denver, Colo., pp. 25-51.
Starks, P.J. 1999. A general heat dissipation sensor calibration equation and estimation of soil water content. Soil Sci. 164:655-661.

Starks, P.J., T.J. Jackson, W.L. Crosson, and T. Meyers. 1999. Automated water content estimates from soil heat dissipation sensors. Preprint Volume, $14^{\text {th }}$ Conf. Hydrol., Dallas, Tex., Amer. Meteorol. Soc., pp. 157-159.

Walker, J.P., G.R. Willgoose, and J.D. Kalma. 2001. One-dimensional soil moisture profile retrieval by assimilation of near-surface observations: a comparison of retrieval algorithms. Adv. Water Res. 24:631-650.

Wang, J.R. and T.J. Schmugge. 1980. An empirical model for the complex dielectric permittivity of soils as a function of water content. IEEE Trans. Geosci. Remote Sensing GE-18:288-295.

Wigneron, J.P., A. Olioso, J.C. Calvet, and P. Bertuzzi. 1999a. Estimating root zone soil moisture from surface soil moisture data and soil-vegetation-atmosphere transfer modeling. Water Resour. Res. 35:3735-3745.

Wigneron, J.P., J.C. Calvet, A. Olioso, A. Chanz, and P. Bertuzzi. 1999b. Estimating root zone soil moisture from the combined use of time series of surface soil moisture and SVAT modeling. Phys. Chem. Earth 24:837-843.

Willmott, C.J. 1981. On the validation of models. Phys. Geogr.2:184-194.

Willmott, C.J. 1982. Some comments on the evaluation of model performance. Bull. Amer. Meteorol. Soc. 63:1309-1313.

Willmott, C.J. and D.E. Wicks. 1980. An empirical method for the spatial interpolation of monthly precipitation within California. Phys. Geogr. 1:59-73. 